\title{
The Landslide Spatial Modelling in Limau District, Tanggamus Regency
}

\author{
Dedy Miswar \\ Geography Education \\ Lampung University \\ Lampung, Indonesia \\ dedy.miswar@fkip.unila.ac.id \\ Endro. P. Wahono \\ Civil Enginering \\ Lampung University \\ Lampung, Indonesia \\ Aristoteles \\ Computer Science \\ Lampung University \\ Lampung, Indonesia
}

\author{
Agus Sutyatna \\ Physical Education \\ Lampung University \\ Lampung, Indonesia
}

Yarmaidi

Geography Education

Lampung University

Lampung, Indonesia

Riyan Yoga Darmawan

Geography Education

Lampung University

Lampung, Indonesia
Wan Abbas Zakaria Agribusiness

Lampung University

Lampung, Indonesia

I Gede Sugiyanta Geography Education Lampung University Lampung, Indonesia

\begin{abstract}
Landslide is one of the natural disasters that often results in loss of property and loss of life as well as damage to facilities and infrastructure that can have an impact on economic and social conditions. The most landslides that occurred in Tanggamus Regency were Limau and Semaka Districts with 4 landslides in the last 7 years, the last landslide and flood disaster occurred on January 13, 2021, in Bulok District. One way to determine areas prone to landslides is to create a spatial model prone to landslides. The purpose of this study is to create a spatial model of the variables in the study, including rainfall, geology, soil type, slope, land use, and landslides. The method used surveys and overlay with ratings, data analysis using descriptive with a spatial approach. The results of the study are spatial data/maps of the distribution of landslides that occurred in Limau District, Tanggamus Regency.
\end{abstract}

\section{Keywords-Modelling, Spatial, Landslide.}

\section{INTRODUCTION}

Landslides or mass movements are closely related to processes that occur scientifically in a landscape. The landscape is a natural formation on the earth's surface such as hills, hills, mountains, mountains, plains, and basins[1]. According to [2]. Landslides are one of the natural disasters that often hit the wet tropics. The damage caused by mass movements is not only direct damage such as damage to public facilities, agricultural land, or human casualties but also indirect damage that paralyzes development activities and economic activities in the disaster area and its surroundings [3-5].

Landslides or often called ground movements are geological events that occur due to the movement of rock or soil masses of various types and types such as falling rocks or large lumps of soil $[6,7]$. In general, landslides are caused by two factors, namely driving factors and triggering factors. The driving factors are the factors that affect the condition of the material itself, while the triggering factors are the factors that cause the material to move $[8,9]$.

Many factors affect the stability of the slopes that lead to landslides. These factors include geological and hydrographic conditions, topography, climate, and weather changes $[10,11]$. In principle, landslides occur when the driving force on the slope is greater than the resisting force. Retaining forces are generally influenced by rock strength and soil density $[12,13]$ While the driving force is influenced by the magnitude of the slope angle, water, load, and density of rock soil [14]. Landslides are one of the natural disasters that often result in property and loss of life and damage to facilities and infrastructure that can have an impact on economic and social conditions $[15,16]$. Landslide is a process of balance disturbance that causes the movement of soil and rock masses from a higher place to a lower place [17-19] This movement occurs because of the force factor located on an uneven ground plane or called a slope [20,21] 
Soil motion is one of the geological processes that occur due to the interaction of several conditions including geomorphology, geological structure, hydrogeology, and land use [22,23]. These mutually influential conditions can create slope conditions that tend to move [24]. Soil movement can be detected by signs such as the appearance of tensile cracks and wrinkles on the surface of the slopes, tilting of trees, loss of straightness of building foundations, and others $[25,26]$.

Tanggamus Regency is one of the regencies in Lampung Province. Tanggamus Regency is geographically located at $104^{\circ} 18^{\prime}-105^{\circ} 12^{\prime} \mathrm{E}$ and between $5^{\circ} 05^{\prime}-5^{\circ} 56^{\prime} \mathrm{S}$. Tanggamus Regency consists of 20 sub-districts, including Wonosobo, Semaka, Bandar Negeri Semuong, Kota Agung, Pematang Sawa, Kota Agung Barat, Kota Agung Timur, Pulau Panggung, Ulu Belu, Air Naningan, Talang Padang, Sumberejo, Gisting, Mount Alip, Pugung. , Bulok, Cukuh Balak, Kelumbayan, Lime, West Kelumbayan. The capital city of Tanggamus Regency is Kota Agung. The position of Tanggamus Regency is in the south of Lampung Province and is directly adjacent to Bukit Barisan Selatan [27].

Tanggamus Regency is located at an altitude of 0 $>1000$ meters above sea level. This area is traversed by the Semangka Fault with a zone width of $\pm 30 \mathrm{~km}$. In some places found some volcanic and tectonic activity as well as the emergence of geothermal. Based on its geographical location, Tanggamus Regency is one of the areas that are included in disaster-prone areas, it is even said that Tanggamus Regency is included in the red zone related to landslide disasters, considering that the majority of the existing areas are hilly and mountainous areas [28,29]. Areas in Tanggamus Regency that are prone to landslides are coastal and riverbanks as well as hilly areas. Even some areas include areas prone to disasters such as Pematang Sawah, Semaka, Wonosobo, Ulu Belu, Kelumbayan, Limau and several other areas [30].

Based on the Regional Regulation of Tanggamus Regency No. 16 concerning the Spatial Planning of Tanggamus Regency in 2011-2031, it stipulates that the landslide area is located in Wonosobo District, Kota Agung, West Agung City, Ulu Belu, Cukuh Balak, West Kelumbayan, Kelumbayan, Watermelon, Pematangsawa, Limau, Bandar Negeri Semoung, Kota Agung Timur and Gisting. Based on the PERDA, it is known that Limau District is one of the districts that are prone to natural disasters, especially landslides [36]. For more details regarding the occurrence of landslides in Tanggamus Regency, the following data is presented on the number of landslides in 7 years:

TABLE I. LANDSLIDE DISASTER DATA IN TANGGAMUS REGENCY IN 2014-2020

\begin{tabular}{|c|c|c|c|c|c|c|c|c|c|}
\hline & \multirow{2}{*}{ District } & \multicolumn{7}{|c|}{ Year } & \multirow[t]{2}{*}{ Number of events } \\
\hline & & 2020 & 2019 & 2018 & 2017 & 2016 & 2015 & 2014 & \\
\hline 1 & Bandar Negeri Semoung & & & & 1 & & & & 1 \\
\hline 2 & Cukuh Balak & & & & & 1 & & 1 & 2 \\
\hline 3 & Gisting & & & & & & 1 & & 1 \\
\hline 4 & Kelumbayan & & & 1 & & & & & 1 \\
\hline 5 & Kelumbayan Barat & & & & 1 & & & & 1 \\
\hline 6 & Kota Agung & & & & & & 1 & & 1 \\
\hline 7 & Kota Agung Barat & & & & 1 & & & & 1 \\
\hline 8 & Kota Agung Timur & & & & 1 & & & & 1 \\
\hline 9 & Limau & & & 1 & & 1 & 1 & 1 & 4 \\
\hline 10 & Pematangsawa & & & & & 1 & & & 1 \\
\hline 11 & Semaka & 1 & & & & 2 & & 1 & 4 \\
\hline 12 & Ulu Belu & & 1 & 1 & & & 1 & & 3 \\
\hline 13 & Wonosobo & 1 & & & 1 & & & & 2 \\
\hline
\end{tabular}

\section{RESEARCH METHOD}

The method in this study uses the survey method. According to [31], the survey is a research method that aims to collect large amounts of data in the form of variables, units, or individuals at the same time. Data is collected through individuals or certain physical samples to be able to generalize what will be studied.

The tools used in the research are used, among others. 1) a set of computers and software used to process data, starting from the input, processing, and output of each spatial data variable; 2) cameras used to document every condition that occurs in the field; 3 ) GPS (global positioning system) which is used to retrieve data related to the location of each spatial data variable; 4) Abney level and clinometer used to collect slope data, and 5) other stationery used to complement and assist in data collection.

Materials used in the research, among others. 1) 1:25,000 scale Digital RBI Map; 2) Rainfall Map of Tanggamus Regency (BMKG) in 2019; 3) Geological Map of Tanggamus Regency (BPN) in 2013; 4) Soil Type Map of Tanggamus Regency (BPN) in 2013; 5) Land Use Map of Tanggamus Regency (BAPPEDA) 
in 2019, and 6) Slope Map of Tanggamus Regency (BAPPEDA) in 2019.

Variables can be defined as attributes of a person or object that vary from one person to another or from one object to another [32;33]. The variables in this study were: rainfall, geology, soil type, slope, and land use. Variables operationally and based on the observed characteristics making it easier for researchers to make observations or measurements carefully on an object of research are as follows.

\section{A. Rainfall}

The influence of rainfall can cause ground movement so that areas that have relatively high rainfall will provide a higher danger of ground movement [37]. The classification of rainfall intensity is presented in Table 2.

TABLE II. ClassifICATION OF RAINFALL INTENSITY

\begin{tabular}{|c|c|c|c|}
\hline & Rainfall Intensity (mm/year) & Parameter & Score \\
\hline 1 & $>3.000$ & Very Heavy Rainfall & 5 \\
\hline 2 & $2.500-3.000$ & Heavy Rainfall & 3 \\
\hline 3 & $2.000-2.500$ & Moderate Rainfall & 1 \\
\hline
\end{tabular}

b. Source: Puslitanak (2004); Yananto dan Sibarani, 2016)

\section{B. Rock Type/Geology}

The types of rocks that make up an area have different levels of danger from one another. Based on the grain size, fine-grained rocks generally have a higher hazard to soil movement, whereas when viewed from their compactness, compact and massive rocks are less likely to be affected by ground motion [34;35]. The classification of rock types is presented in Table 3.

TABLE III. CLASSIFICATION OF ROCK TYPES

\begin{tabular}{|c|l|c|}
\hline & Rock Type & Score \\
\hline 1 & Volcanic Materials-2 (Qvsb, Qvst, Qvb, Qvt) and Sediment Materials-2 (Tmb, Tmbl, Tmtb) & 5 \\
\hline 2 & Sediment Material-1 (Tmn, Tmj) & 4 \\
\hline 3 & Volcanic Material-1 (Qvsl, Qvu, Qvcp, Qvl, Qvpo, Qvk, Qvba) & 3 \\
\hline 4 & Alluvial Material (Qav, Qa, a) & 1 \\
\hline
\end{tabular}

c. Source: Puslitanak (2004; Paratiningtyas, 2015).

\section{Soil Type}

The type of soil that has the potential for landslides, especially when it rains, is the type of soil that is less dense in this case is soil that has a texture of sand and clay or clay with a thickness of more than $2.5 \mathrm{~m} \mathrm{[38].} \mathrm{Classification} \mathrm{of} \mathrm{soil} \mathrm{types} \mathrm{is} \mathrm{presented} \mathrm{in}$ Table 4.

TABLE IV. CLASSIFICATION OF SOIL TYPES IN LANDSLIDE SENSITIVE

\begin{tabular}{|l|l|c|c|}
\hline & Soil Type & Soil Sensitivity & Score \\
\hline 1 & Alluvial, Gleysol, Planosol, Gray Hydromorphic, Groundwater Laterite & Insensitive & 5 \\
\hline 2 & Latosol & Little Sensitive & Little Sensitive \\
\hline 3 & Brown forest soil, Non calcic brown, Mideteranian & Sensitive & \\
\hline 4 & Andosol, Lateric, Grumosol, Podsol, Podsolik & Extra Sensitive & 2 \\
\hline 5 & Regosol, Litosol, Renzina & 2 & 1 \\
\hline
\end{tabular}

for landslides [42;43] The classification of the slope

\section{Slope}

Landslides generally occur in sloping areas. The higher the slope of the land, the greater the potential can be seen in table 5 .

TABLE V. CLASSIFICATION OF SLOPE

\begin{tabular}{|l|l|l|c|}
\hline & Slope (\%) & Slope Classification & Score \\
\hline 1 & $0-8$ & Flat & 1 \\
\hline 2 & $8-15$ & Sloping & 2 \\
\hline 3 & $15-25$ & Rather Steep & \\
\hline 4 & $25-45$ & Steep & 3 \\
\hline 5 & $>45$ & Very Steep & 4 \\
\hline
\end{tabular}

e. Source: Guidelines for Formulating Land Rehabilitation and Soil Conservation Patterns (1986; Nafi and Rizky, 2017). 


\section{E. Land Use}

Land uses such as rice fields as well as dry fields and shrubs, especially in areas that have steep slopes, are generally prone to landslides $[44 ; 45]$ Classification of land use can be seen in table 6 .

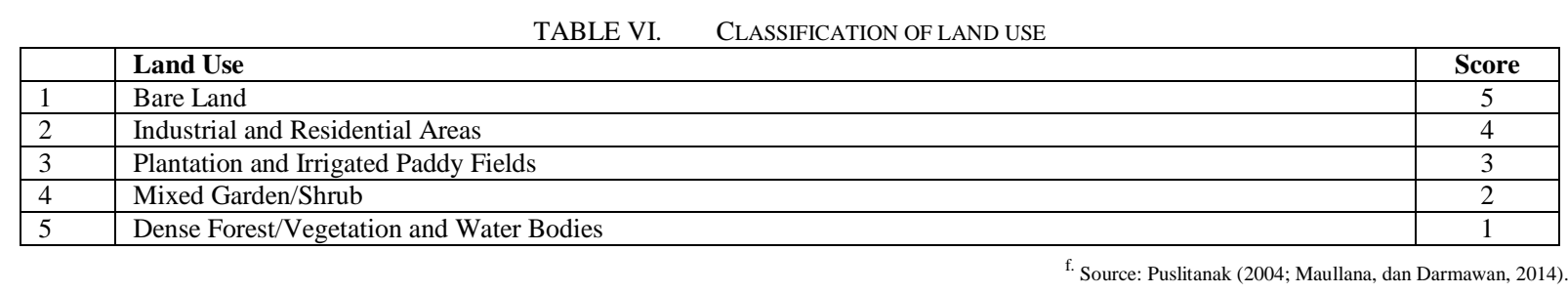

In this study, there are three data collection techniques used, namely: Documentation, Observation, and Interview. The data analysis used is descriptive with a spatial approach based on the results of overlapping (Map Overlay), and ratings [39].

\section{RESULT AND DISCUSSION}

\section{A. Result}

Following the research objectives, make spatial models of rainfall, geology, soil types, slopes, land use, and landslides. The explanation of each spatial data is as follows:

\section{1) Rainfall}

Rainfall is one of the climate elements that has a big role in the occurrence of landslides. Rainwater infiltration into the soil layer will saturate the soil and weaken the slope-forming material, thus triggering landslides. Rain with high rainfall and intensity will provide a higher hazard of ground movement. The following table and map of the spatial distribution of rainfall in Limau District are presented below.

\begin{tabular}{l} 
TABLE VII. \\
\begin{tabular}{|l|l|l|l|}
\hline \multicolumn{1}{|c|}{ Rainfall } & \multicolumn{1}{c|}{ Area $\left.\mathbf{( k m}^{2}\right)$} & Percentage $(\boldsymbol{\%})$ \\
\hline 1 & $2000-2500 \mathrm{~mm}$ & 99,15 & 47,37 \\
\hline 2 & $2500-3000 \mathrm{~mm}$ & 110,14 & 52,63 \\
\hline Total & $\mathbf{2 0 9 , 2 9}$ & $\mathbf{1 0 0 , 0 0}$ \\
\hline
\end{tabular} \\
\hline
\end{tabular}

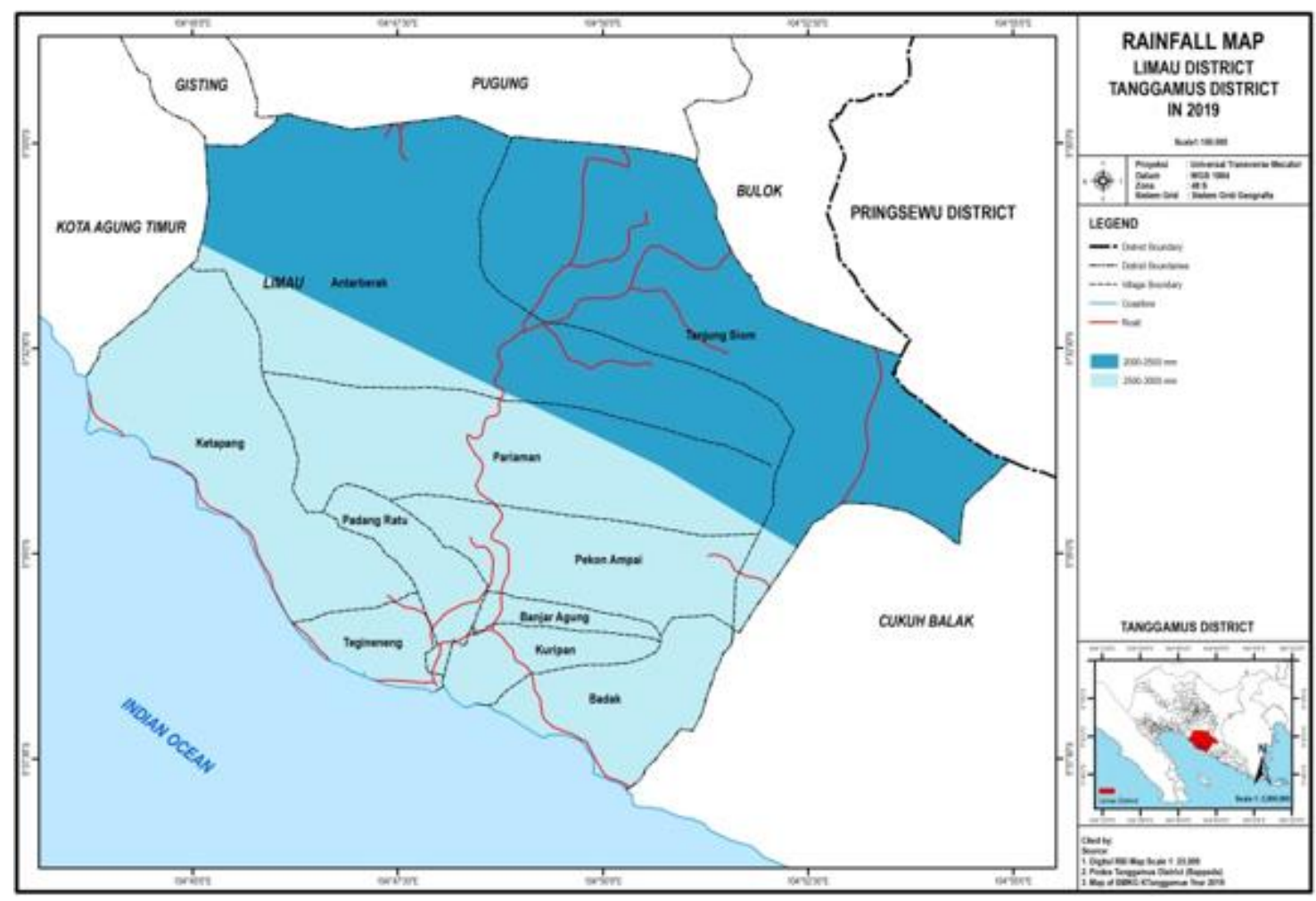

Fig. 1. Rainfall Map of Limau District 
Based on table 1 Figure 1, it can be seen that the rainfall in Limau District is divided into two types, 2000-2500 $\mathrm{mm}$ and 2500-3000 $\mathrm{mm}$. Rainfall with an intensity of $2500-3000 \mathrm{~mm}$ is the rainfall that dominates the Limau District area with an area of $110.4 \mathrm{~km} 2(52.63 \%)$ of the total area of Limau District. As for the area of rainfall with a rainfall intensity of 2000-2500 is the smallest rainfall with an area of $99.15 \mathrm{~km} 2$ or $47.37 \%$ of the total area of Limau District. The spatial distribution of rainfall in Limau District with an intensity of 2500-3000 mm occurs in almost all Antarberak Villages and Siom Villages. Meanwhile, rainfall with an intensity of 2000-2500 $\mathrm{mm}$ is spread in all villages in Limau District, such as the villages of Ketapang, Pariaman, Padang Ratu, Ampai, Banjar Agung, Tegineneng, Kuripan, and Badak. The indicator of climate is rainfall, where rainfall can trigger landslides, this is closely related to the triggering factors for landslides. With high rainfall, it will cause the soil to become loose and the binding capacity of the soil to be weak so that the strength of the soil in maintaining stability is lost and erosion, soil erosion, and land landslides are easy. Landslides are easy to occur at the beginning of every season.

\section{2) Slope}

The topographic element that has the greatest influence on landslides is the slope [28]. The steeper the slope, the bigger and faster the landslide occurs. The following is a table and map of the spatial distribution of slopes in Limau District.

TABLE VIII. SLOPE AREA IN LIMAU DISTRICT IN 2020
\begin{tabular}{|l|l|l|l|}
\hline \multicolumn{1}{|c|}{ Slope } & \multicolumn{1}{c|}{ Area $\left(\mathbf{k m}^{2}\right)$} & \multicolumn{1}{c|}{ Percentage (\%) } \\
\hline 1 & $25-45 \%$ Slope & 30,02 & 14,34 \\
\hline 2 & $15-25 \%$ Slope & 179,27 & $\mathbf{1 0 0 , 0 0}$ \\
\hline Total & $\mathbf{2 0 9 , 2 9}$ & \multicolumn{2}{c|}{ h. Source: Data Processing Results, 2020.} \\
\hline
\end{tabular}

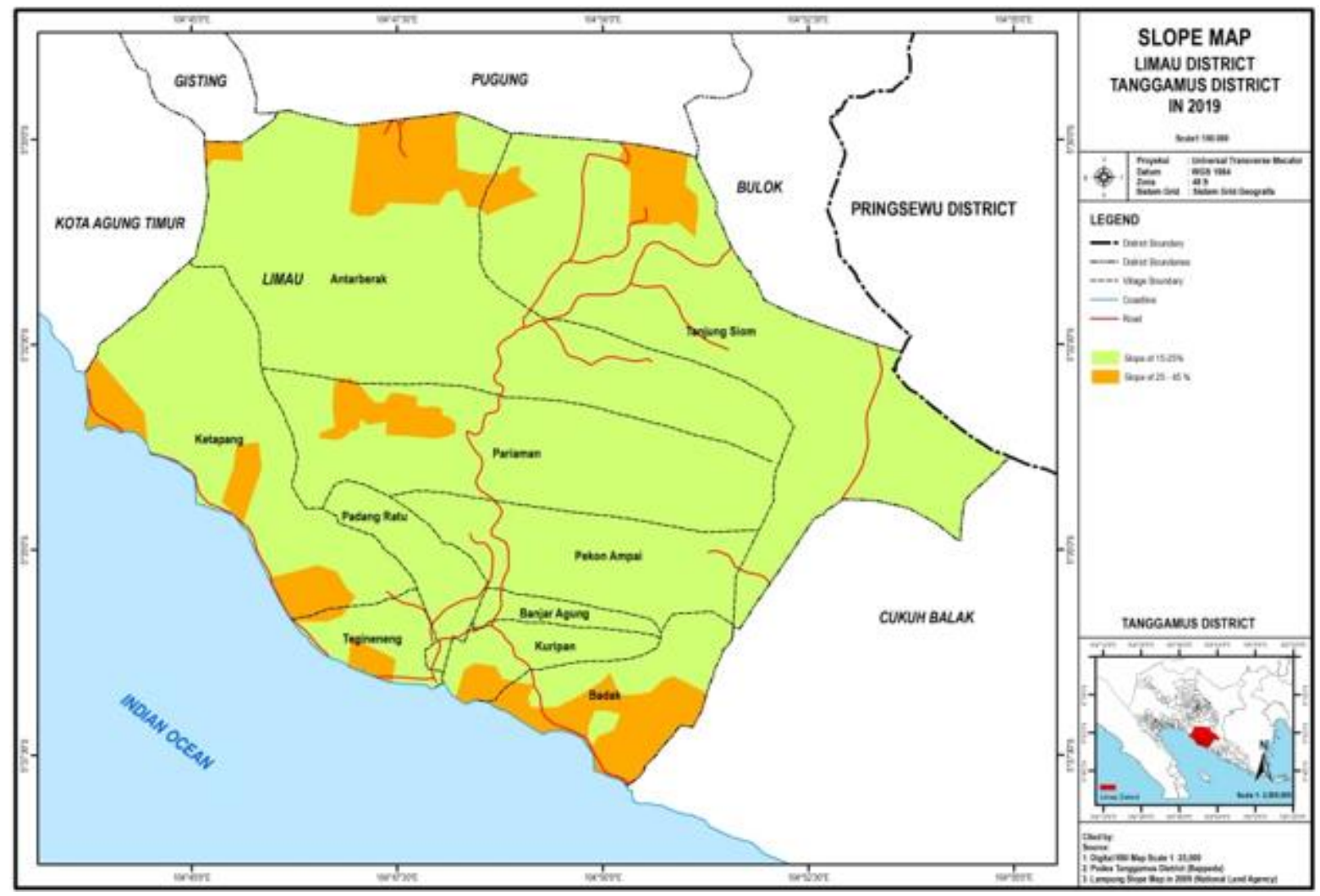

Fig. 2. Slope Map of Limau District

Based on table 2 and figure 2, it can be seen that in Limau District, there are two criteria for steep slopes and a rather steep slope with a slope of $25-45 \%$ having a total area of $30.02 \mathrm{~km} 2$ or $14.34 \%$ of the total area of Limau District. While the slope of $15-25 \%$ is the slope that dominates in the Limau District area with an area of $79.27 \mathrm{~km} 2$ or $85.66 \%$ of the total area of the Limau District. The following figure shows the existing conditions in the field which are located at 5'33'40,86's 104'52'24,5''E and 5'31'44,71''S, $104^{\circ} 50$ '3,66' $\mathrm{E}$. Data was taken during the survey on August 22, 2020, at 07.13 WIB. 

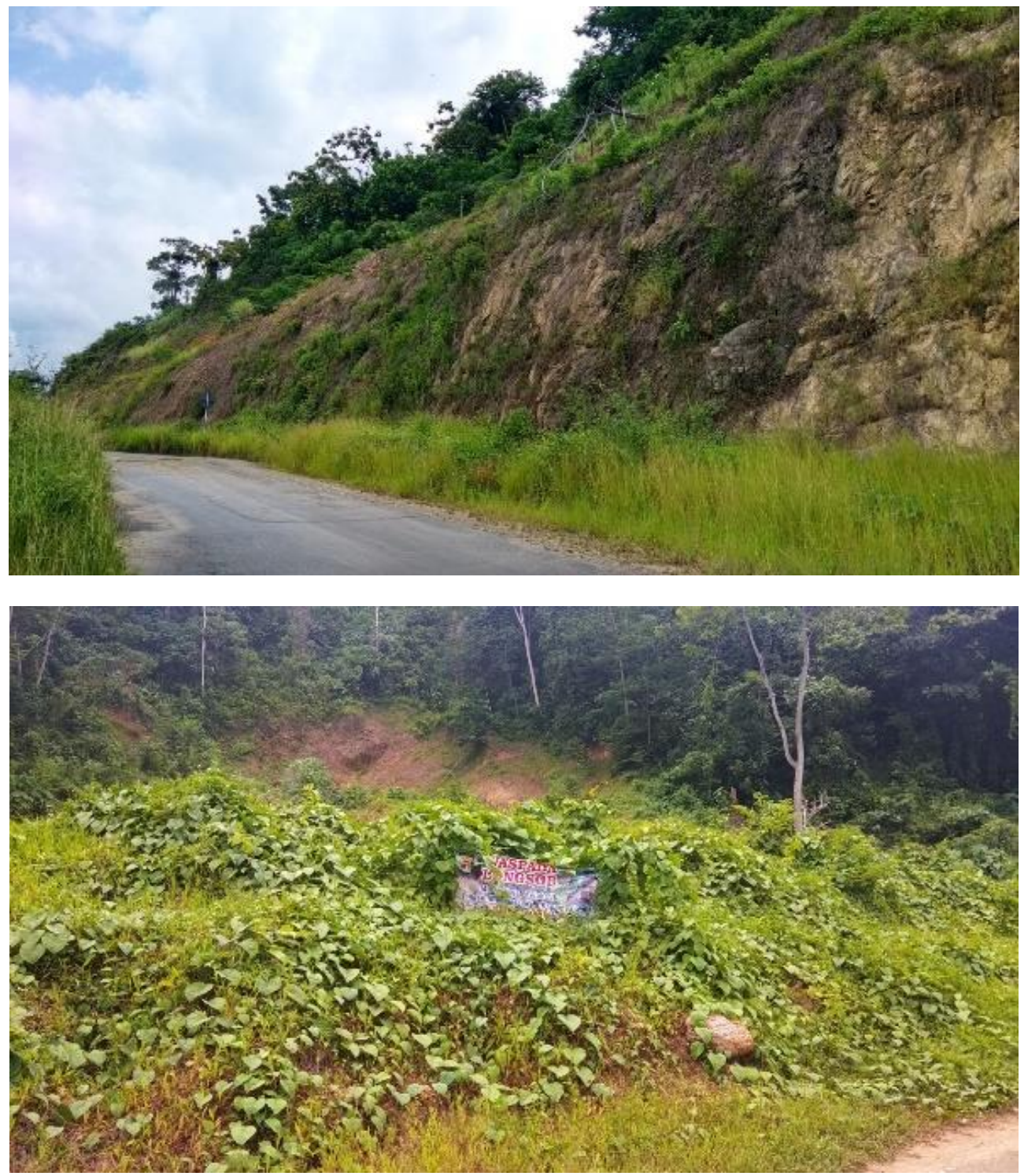

Fig. 3. Landslide with Steep Slope (a and b) in Pekon Tanjung Siom I

3) Soil Type

Soil type factors have different sensitivity to landslides. The sensitivity of landslides is whether or not landslides are easy as a function of various soil physical and chemical properties [47]. The following is a table and map of the spatial distribution of soil types in Limau District in 2020.

TABLE IX. SOIL TYPE AREA IN LIMAU DISTRICT IN 2020

\begin{tabular}{|c|l|c|c|}
\hline & Soil Type & Area $\left(\mathbf{k m}^{\mathbf{2}}\right)$ & Percentage (\%) \\
\hline 1 & Alluvial & 6,79 & 3,24 \\
\hline 2 & Andosol & 10,37 & 4,95 \\
\hline 3 & Latosol & 192,13 & 91,80 \\
\hline Total & $\mathbf{2 0 9 , 2 9}$ & $\mathbf{1 0 0 , 0 0}$ \\
\hline
\end{tabular}

${ }^{\text {i. }}$ Source: Data Processing Results, 2020 


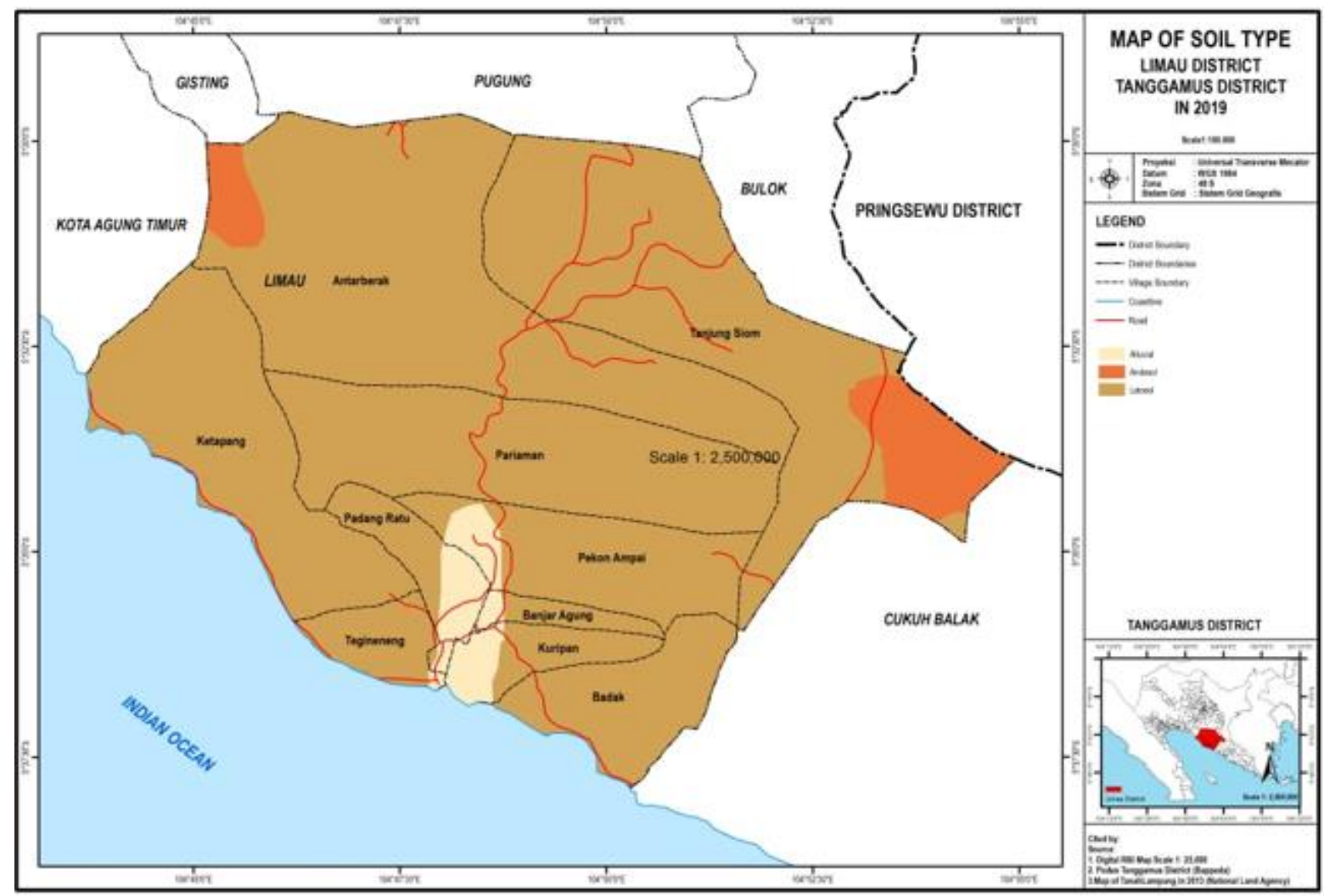

Fig. 4. Soil Type Map of Limau District

Table 3 and Figure 4 show that the area of soil types in Limau District, try to find out that Limau District has three types of alluvial soil, andosol, and latosol. The dominant soil type in the Limo District is latosol with an area of $192.3 \mathrm{~km} 2$ or $91.82 \%$ of the total area of Limau District. Andosol soil type has an area of $10,307 \mathrm{~km} 2$ or $4.95 \%$ of the total area of Limau District while alluvial soil type is the type of soil with the smallest area, namely with an area of 6.79 $\mathrm{km} 2$ or $3.24 \%$ of the total area of Limau District.
Land use is one of the determinants of landslides. This is due to the many changes in land use that have occurred, one example of which is vegetation land (as land cover) from forest stands or dense vegetation to mixed gardens, shrubs, settlements, or becoming vacant land will greatly affect slope stability, especially in forest areas converted to agricultural land [46]. The following is a table and map of the spatial distribution of land use in Limau District.

\section{4) Land Use}

TABLE X. LAND-USE AREA IN LIMAU DISTRICT IN 2020

\begin{tabular}{|c|l|c|c|}
\hline \multicolumn{1}{|c|}{ Land Use } & Area $\left(\mathbf{k m}^{\mathbf{2}}\right)$ & Percentage (\%) \\
\hline 1 & Secondary Dryland Forest & 9,12 & 4,36 \\
\hline 2 & Settlement & 2,45 & 1,17 \\
\hline 3 & Plantation & 15,42 & 7,37 \\
\hline 4 & Dryland Mixed Bush Farming & 176,88 & 84,51 \\
\hline 5 & Savanna & 0,42 & 0,20 \\
\hline 6 & Shrubs & 4,93 & 2,36 \\
\hline 7 & River & 0,08 & 0,04 \\
\hline Total & $\mathbf{2 0 9 , 2 9}$ & $\mathbf{1 0 0 , 0 0}$ \\
\hline
\end{tabular}

j. Source: Results of Recapitulation of Land Use Map Data in Limau District in 2020. 


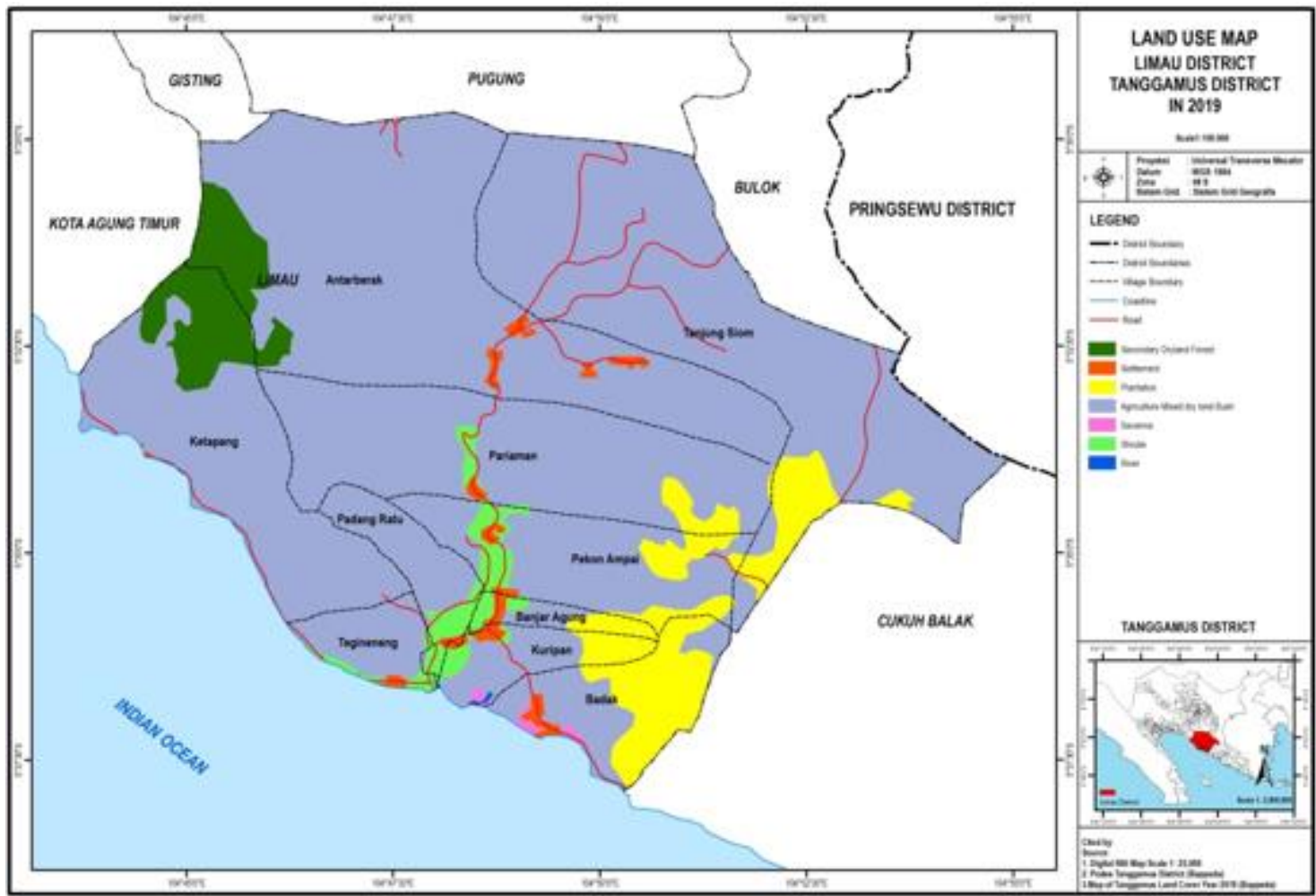

Fig. 5. Land Use Map of Limau District

In the table and map above, the types of land use in Limau District are divided into 7 types, namely dryland forest, settlements, plantations, dryland agriculture mixed with shrubs, savanna, shrubs, and rivers or water bodies. The area of land use that dominates is dry land mixed with shrubs with a total area of $176.88 \mathrm{~km} 2$ or $84.51 \%$ of the total area of Limau District. Land use with the smallest area is the use of savanna land types with an area of $0.42 \mathrm{~km} 2$ or $0.2 \%$ and rivers with an area of $0.08 \mathrm{~km} 2$ or $0.04 \%$.
The type of land use also affects the occurrence of landslides. In the use of nonpaddy land, landslides have only begun to occur in areas with a slope of $>8 \%$. However, on slopes $>25 \%$ the use of paddy fields and nonrice fields tends to have the same landslides, namely medium to high.

Nonpaddy fields that experience landslides generally occur in the use of shrubs and dry fields. This is because the existing roots have not been able to bind the soil.

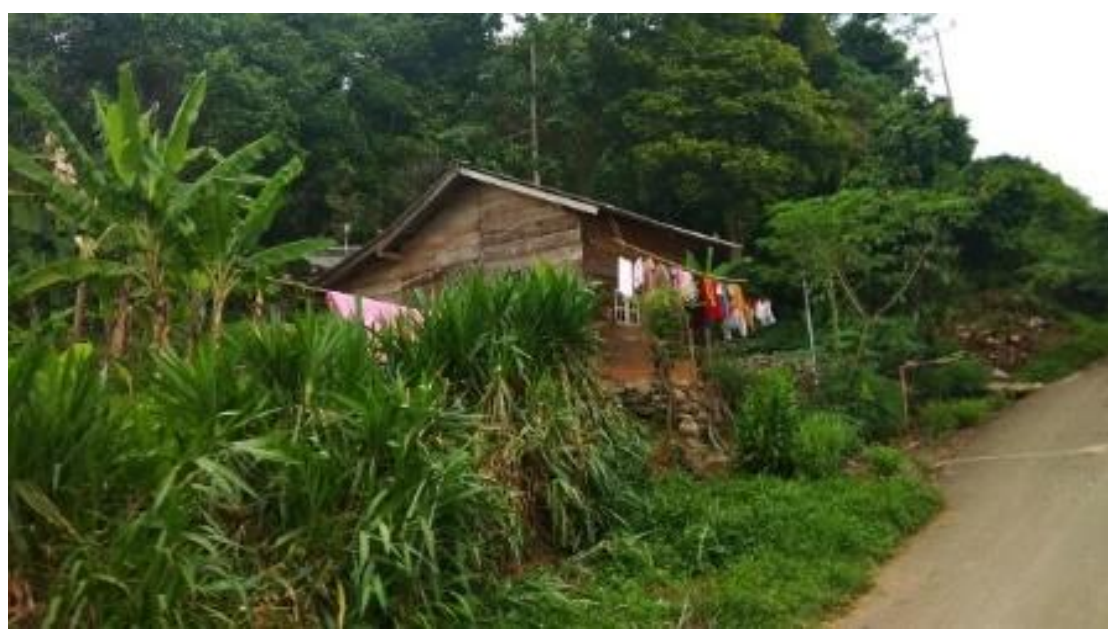




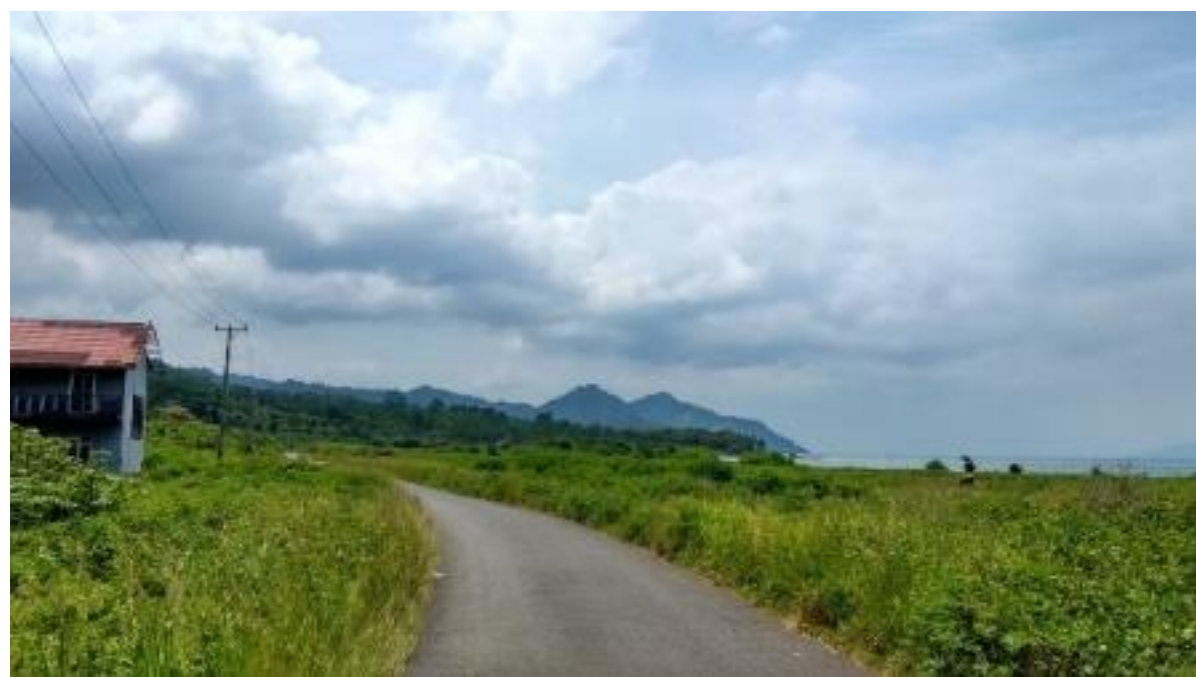

Fig. 6. Land Use for Settlements (a) in Pekon Tanjung Siom, location at 5 $33^{\prime} 38^{\prime \prime} S 104^{\circ} 44^{\prime} 31^{\prime \prime E}$ and (b) Land Use for Savanna in Pekon Kuripan, location at 5 $33^{\prime} 13^{\prime \prime} \mathrm{S} 104^{\circ} 43^{\prime} 46^{\prime} \mathrm{BT}$

\section{5) Geology}

Geology is one of the drivers of landslides apart from rainfall, slope, land use, and soil types. Geology is identical to the rock formation process itself. For more details regarding the spatial distribution of geological area in Limau District, it can be seen in the following table and map.

TABLE XI. GeOlogy AREA IN Limau District IN 2020

\begin{tabular}{|l|c|c|c|}
\hline & Geology & Area $\left(\mathbf{k m}^{\mathbf{2}}\right)$ & Percentage (\%) \\
\hline 1 & Sediment-1 & 190,34 & 90,95 \\
\hline 2 & Volcanic-1 & 18,95 & 9,05 \\
\hline \multicolumn{2}{|c|}{ Total } & $\mathbf{2 0 9 , 2 9}$ & $\mathbf{1 0 0 , 0 0}$ \\
\hline
\end{tabular}

k. Source: Results of Recapitulation of Geological Map Data in Limau District in 2020.

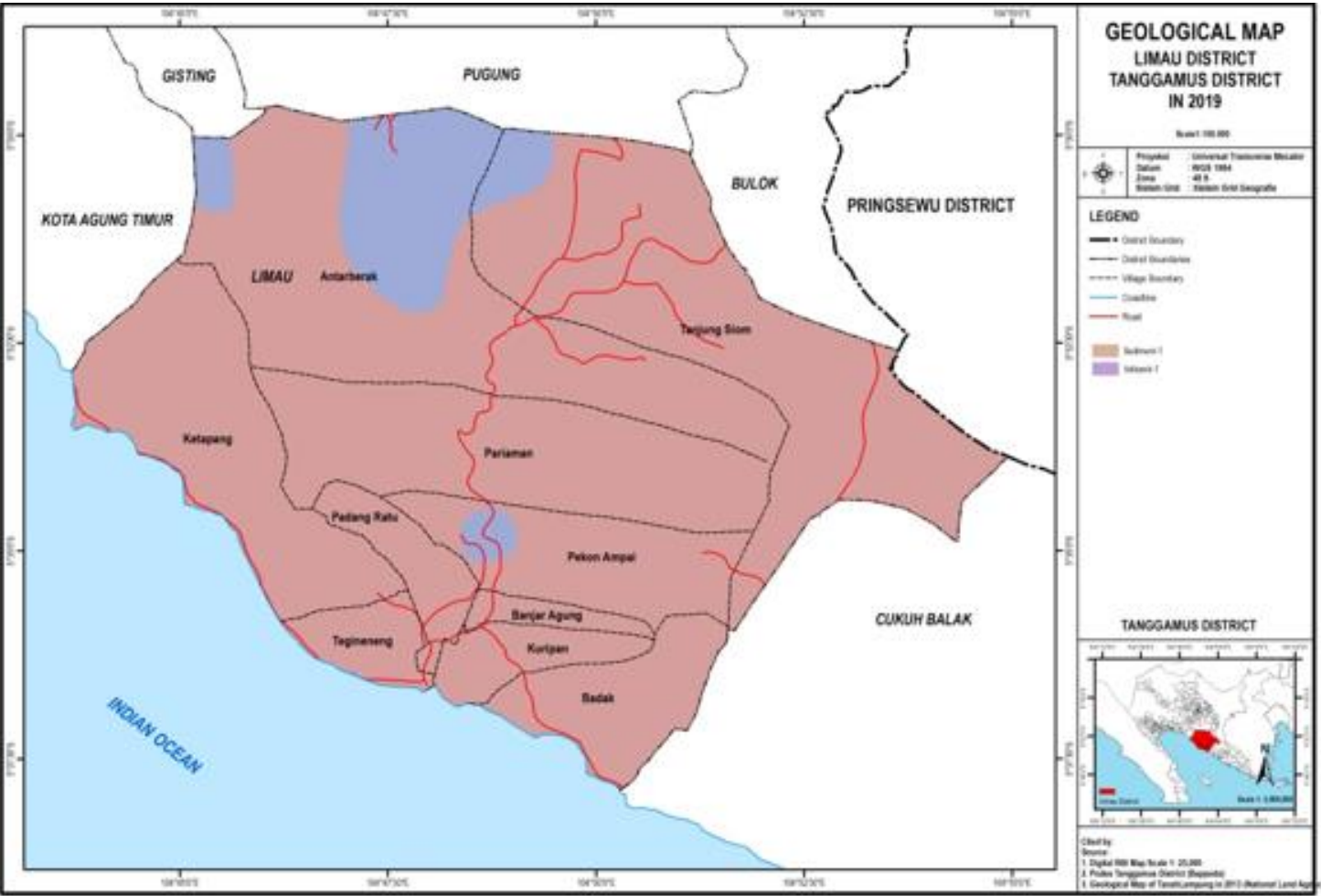

Fig. 7. Geology Map of Limau District 
Table 11 and Figure 7 above can be seen that the geology in the District is divided into two, namely sedimentary and volcanic. The geological area in the form of sediment in Limau District is the area that dominates or is the largest with an area of $190.34 \mathrm{~km} 2$ or $90.95 \%$ of the entire Limau District. while geology with volcanic types has an area of $18.95 \mathrm{~km} 2$ or $9.05 \%$ of the total area of Limau District.

Sedimentary rocks are formed from pre-existing rocks that have been weathered, driven by water, erosion by wind and processes, diagnosis, transportation, and lithification. oceans or lakes. At first, sedimentary rocks were soft rocks, but because of the diagenetic process, the soft rocks turned hard. Sedimentary rocks that are formed chemically or organically have one thing in common, namely that they are formed by the accumulation of solutions. In addition to the sedimentary rocks above, there is also a type of sedimentary rock that mostly contains insoluble materials, such as debris deposits on mountain slopes as a result of the destruction of rocks that have undergone weathering, sunlight, or wind erosion.
Igneous rock is a type of rock formed from magma that cools and hardens, with or without a crystallization process, either below the earth's surface known as intrusive (plutonic) rock or above the earth's surface known as an extrusive rock (volcanic). Volcanism is an activity related to the movement of magma. Magma as an incandescent liquid silicate mass is very active in moving in all directions, either vertically, obliquely, infiltrating, or horizontally, moving on the surface of the earth or only in the earth.

\section{6) Land Unit}

The land unit is the smallest mapping and observation unit that has the same physical factors on the land unit in the sense that the erosion that occurs on the land in a land unit is considered the same. In the analysis of each land, the unit is limited based on the difference in slope, type of land use, and the type of soil found in the research area. Combining by way of overlaying slope class maps with maps of land use types and maps of soil types is a way to determine land unit maps. By combining these physical factors using GIS, a map of land units is obtained.

To see the distribution of land units can be seen in figure 8 .

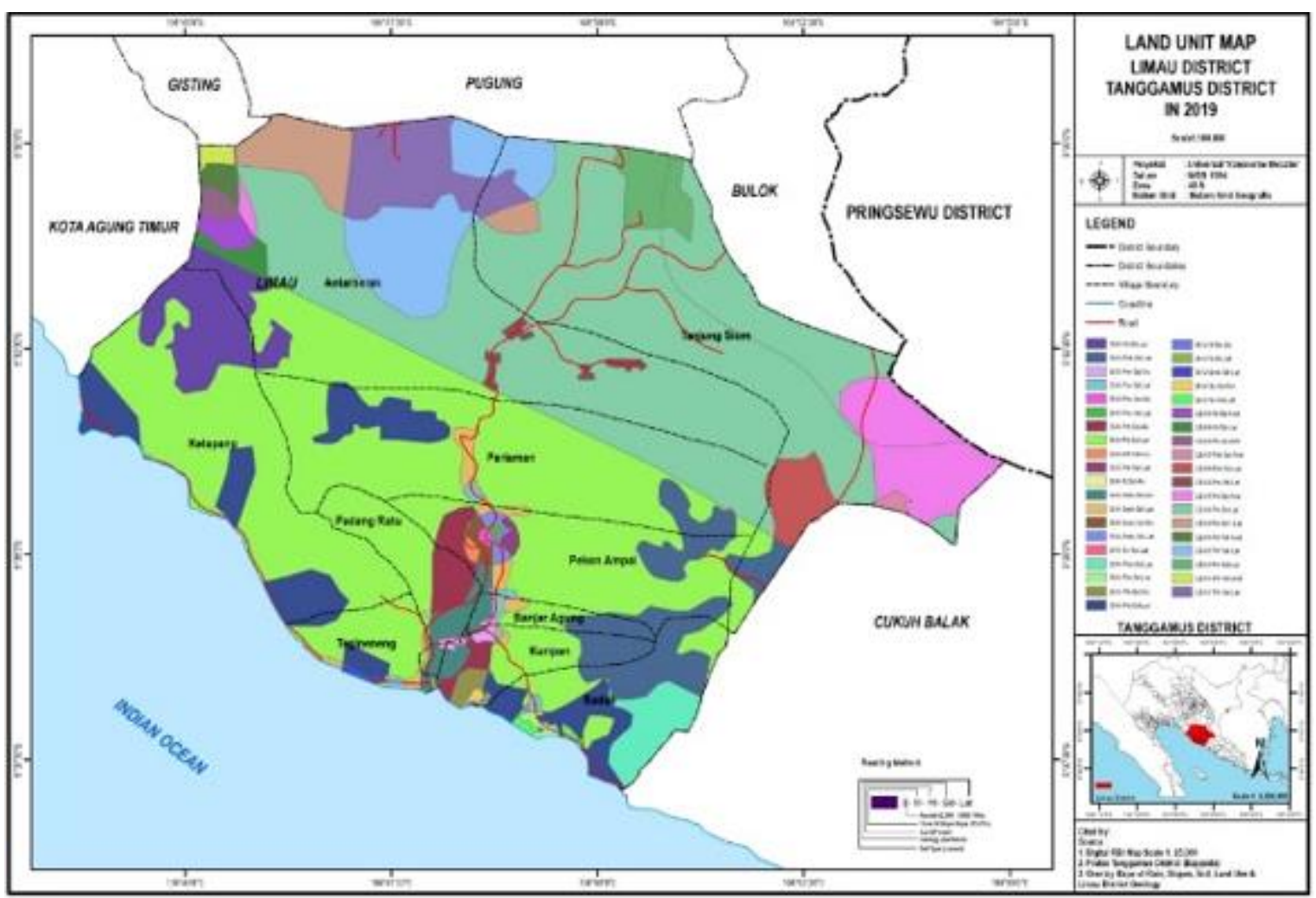

Fig. 8. Land Unit Map of Limau District

\section{7) Landslide Vulnerability}

Landslide vulnerability in Limau District is determined by five parameters, namely rainfall, slope, soil type, land use, and geology (rock type). Then categorized into assessment criteria by scoring. For more details, see the table and map of the accessibility assessment below. 
TABLE XII. LANDSLIDE VULNERABILITY AREA IN LIMAU DISTRICT IN 2020

\begin{tabular}{|l|l|c|c|}
\hline & Landslide Vulnerability & Area $\left.\mathbf{( k m}^{\mathbf{2}}\right)$ & Percentage (\%) \\
\hline 1 & Vulnerable & 198,72 & 94,95 \\
\hline 2 & Non Vulnerable & 10,57 & 5,05 \\
\hline \multicolumn{2}{|c|}{ Total } & $\mathbf{2 0 9 , 2 9}$ & $\mathbf{1 0 0 , 0 0}$ \\
\hline
\end{tabular}

1. Source: Results of Recapitulation of Landslide Hazard Map Data in Limau District in 2020

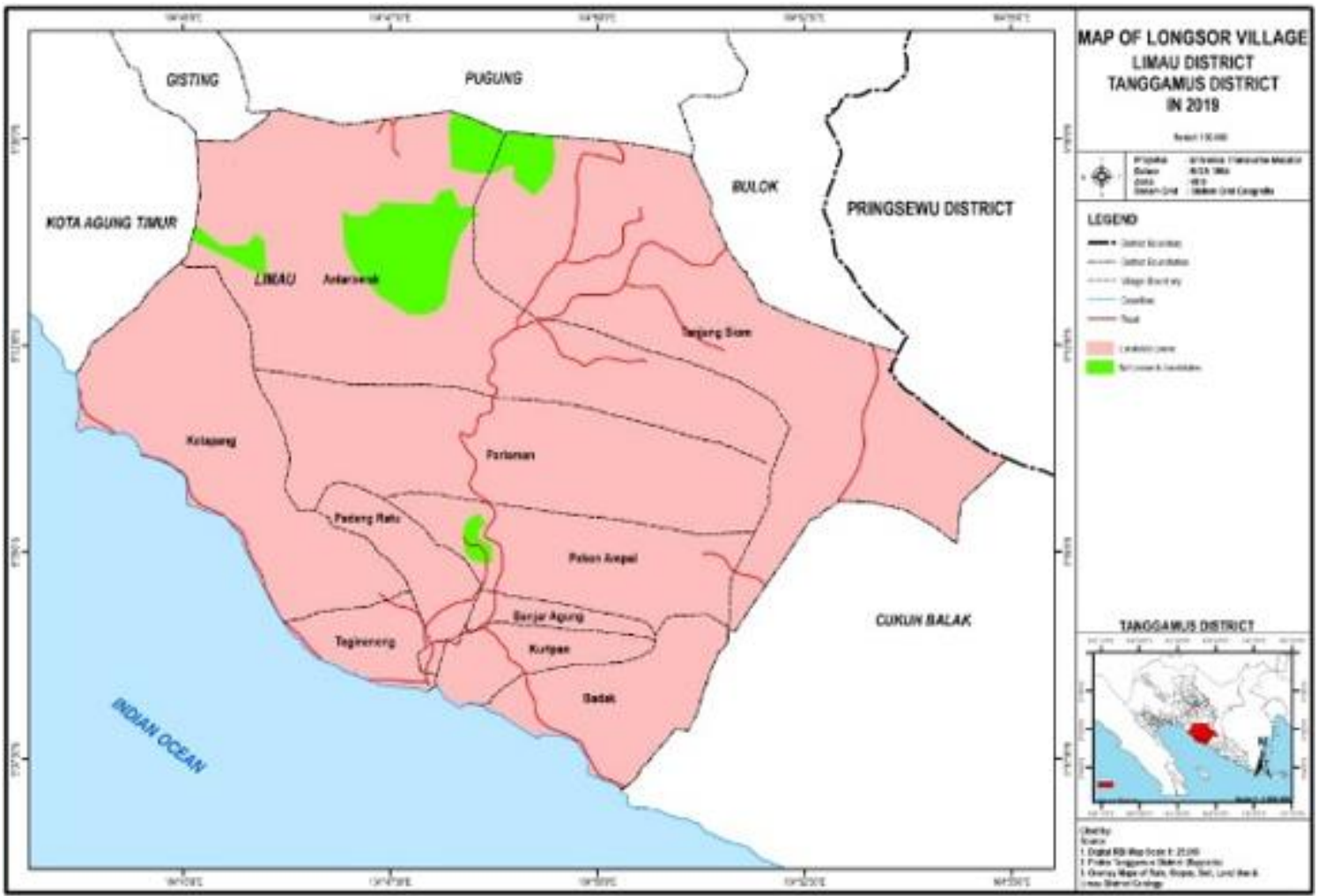

Fig. 9. Landslide Vulnerability Map of Limau District

Based on table data on the area of landslide susceptibility in Limau District, it is known that landslide susceptibility is divided into two, namely landslide susceptibility with vulnerable and non prone categories. for the vulnerable category is the most dominating in Limau District, this is evidenced by the area for landslide-prone areas with a prone category of
$198.72 \mathrm{~km} 2$ or 94.95 percent of the total area of Limau District. As for the category due to landslides that are not vulnerable, it is the smallest area with an area of $10.57 \mathrm{~km} 2$ or $5.05 \%$ of the total area of Limau District. the spatial distribution of landslide hazard in Limau District in the form of a map.

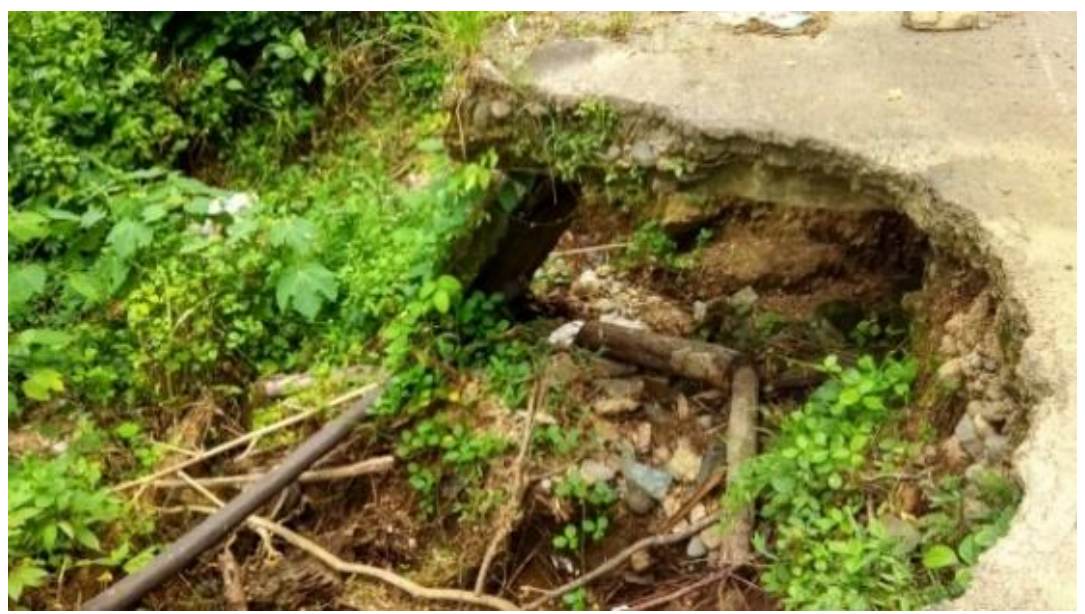




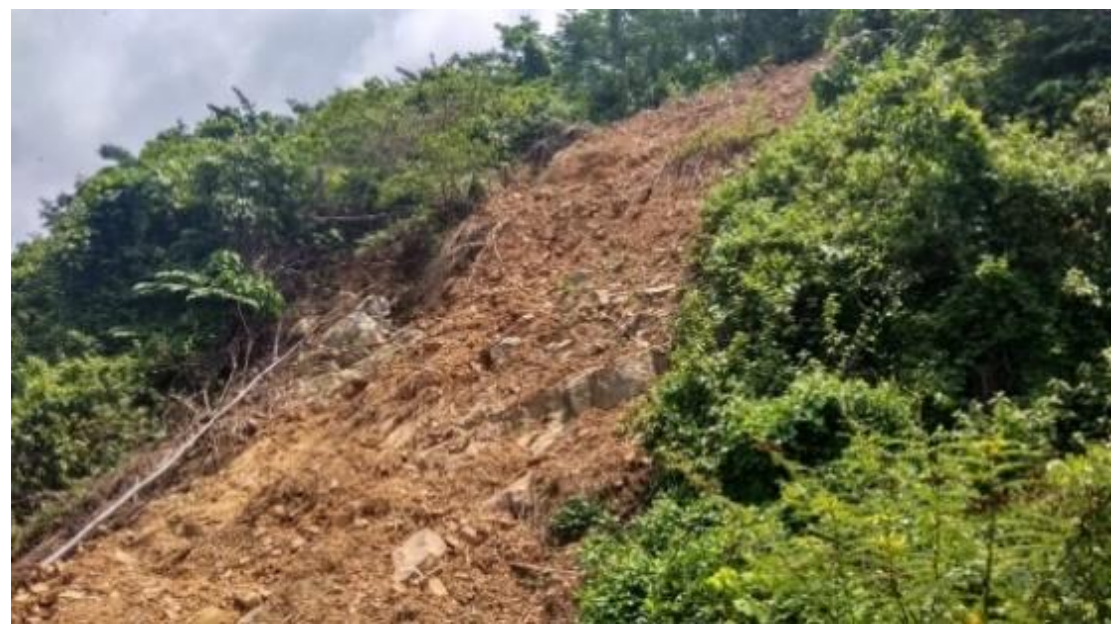

Fig. 10. Landslide Prone Areas (a and b) in Pekon Tanjung Siom Coordinates: 5³3'54" South Latitude 104 $44^{\prime} 45^{\prime \prime}$ East Longitude

\section{B. Discussion}

Rainfall is one of the factors that have a big role in the occurrence of landslides. This is also reinforced [48] that several factors cause landslides including major factors (slope, fault, texture, regolith depth, and geology); minor factors (slope shape, aggregation, permeability, drainage, and structure) as well as trigger factors, namely natural (rainfall and soil movement) and artificial (cutting of upright cliffs and slope loads). Based on the results of identification in the field, it is known that rainfall is a trigger factor that greatly influences the occurrence of landslides.

Based on research data, it is known that Limau District is dominated by rainfall in the humid category with rainfall intensity of $2000-2500 \mathrm{~mm} /$ year. rainfall with an intensity of 2000-2500 mm/year spread over Pekon Antarbrak, Pariaman, and Tanjung Siom. Villages with rainfall intensity of 2000-2500 mm/year are located in Tanjung Siom Village with an area of $48.06 \mathrm{~km} 2$ or $22.97 \%$. Meanwhile, the village with the smallest rainfall intensity of $2000-2500 \mathrm{~mm} / \mathrm{year}$ is located in Pekon Pariaman with an area of $5.36 \mathrm{~km} 2$ or $2.56 \%$. Rainfall with an intensity of 2500-3000 $\mathrm{mm}$ /year spreads over Pekon Antarbrak, Badak Banjar Agung, Ketapang, Kuripan, Padang Ratu, Pariaman, Pekon Ampai, Tanjung Siom and Tegineneng. Of these villages, the largest area with rainfall intensity of 2500-3000 mm/year is Pekon Ketapang with an area of $27.12 \mathrm{~km} 2$ or $12.96 \%$ of the total area of Limau District and Pekon Pariaman with an area of 24.80 $\mathrm{km} 2$ or $11,85 \%$ of the total area of Limau District. This makes the area a driving factor for landslides. Meanwhile, the smallest rainfall intensity of 2500$3000 \mathrm{~mm} /$ year is located in Pekon Tanjung Siom with an area of $1.79 \mathrm{~km} 2$ or 0.85 percent.

In addition to rainfall, topographical elements also have a very large influence on landslide disasters. In terms of slope, the steeper the slope of an area, the greater the possibility of landslides. However, not all areas that have steep slopes have the potential for landslides, this is determined by the constituent materials of the person, such as vegetation, soil types, and so on. This is also supported by the opinion [49] which states that the higher the slope, the greater the potential for landslides to occur.

Land with a steeper slope, both by human activities and natural processes, will cause the slope to become unstable. Limau District has two types of slopes, namely steep with a slope of 25 to $45 \%$ and rather steep with a slope of 15 to $25 \%$. Slopes with steep slopes are more prone to landslides than gentle slopes. Physically, a landslide will occur or not depending on the magnitude of the force that holds the rock or soil on the slope and the magnitude of the force that comes out of the slope or the force that pulls the slope material to fall. If the retaining force is greater than the pulling force, then landslides will not occur, but if the retaining force is less than the pulling force, then landslides will occur. The pulling force that comes out of the slope will be greater with the increasing load of the slope and the slope of the slope. Meanwhile, for a rather steep slope will cause landslides but not as severe as on a steep slope. Most of the area in Limau District consists of a rather steep slope.

Then, the type of soil is one factor that also plays an important role in determining an area that can be called landslide-prone. This is because the type of soil is closely related to the infiltration process when it rains in an area. an area that has a type of soil that has a sandy texture will automatically be easier for landslides to occur because water that enters the soil will be directly forwarded. Therefore, the type of soil is one of the parameters for determining the occurrence of landslides. This is following research according to [50] the parameters in the landslide vulnerability assessment process are geological conditions and regolith depth.

Based on the results of the study, it is known that the dominance in the sub-district is latosol with an area of $192.13 \mathrm{~km}^{2}$ or $91.80 \%$ of the total Limau 
District. We know that latosol soil types have a rather sensitive sensitivity to the ability of the soil to bind water in the soil. The largest areas in Limau District that have latosol soil types are Pekon Antarbrak and Tanjung Siom. Meanwhile, the smallest area with latosol soil type is Pekon Banjar Agung with an area of $2.10 \mathrm{~km}^{2}$ or $1 \%$.

According to [40] the latosol soil type has properties that are somewhat sensitive to erosion, while the Andosol soil type has properties that are sensitive to erosion. This Andosol soil type is spread in Pekon Antarbrak and Tanjung Siom. Because the nature of this type of Andosol soil is sensitive to erosion, of course, it will trigger landslides so that the two villages are prone to landslides.

Land use plays an important role in determining the parameters of landslide occurrence. Land use is closely related to the number of changes in vegetation (as land cover) from forest stands or dense vegetation to mixed gardens, bush bushes, settlements, or becoming vacant land will greatly affect the stability of slopes, especially in forest areas that are converted into agricultural land. [51] states that the role of vegetation in landslide cases is very complex. In certain cases plants that live on slopes with a certain slope.

Based on the results of research on this matter, it is known that the dominant land use is dry land mixed with shrubs with a total area of $176,88 \mathrm{~km} 2$ or 24.5 $1 \%$ of the total area of Limau District. The use of dry land mixed with shrubs is spread over the villages of Antarbrak, Badak, Banjar Agung, Ketapang, Kuripan, Padang Ratu, Pariaman, Pekon Ampai, Tanjung Siom, and Tegineneng. The use of dry matter agricultural land mixed with shrubs of course has very little vegetation on it and the absence of large trees that support the soil. From this and looking at the conditions on the ground, it is very possible that this type of land use has a very large potential to occur during heavy rains.

The results of research in the field when interviewing one of the residents it was known that before it became agricultural land the land used to be land that had a lot of trees. However, due to the expansion of land for agricultural use, the land has changed. As a result of these activities, which do not pay serious attention to soil and water conservation, it creates new problems that will later threaten landslides.

Geology is a rock structure and mineralogical composition which is one of the factors causing landslides. if we look in mountainous areas, the dominant types of rock types are craft and volcanic materials. while in the Limau District area, the rock types are sedimentary and volcanic. Assume from this that the type of rock has watertight properties so that in saturated conditions when it rains it will become a sliding field for landslides to occur.

Based on the table and the results of the study, it is known that the geology that dominates in Limau District is sedimentary geology type where the distribution is located in Pekon Antarbrak, Badak, Banjar Agung, Ketapang, Kuripan, Padangratu, Pariaman, Ampat, Tanjungsiom, and Tegineneng. According to [52] landslides are a 3D geological phenomenon. Landslides (soil movements) in Indonesia, generally occur on steep slopes formed from unconsolidated volcanic deposits. Therefore, geomorphological, hydrological, and land cover characteristics can be used as indicators that a landslide has occurred in an area. Steep slopes that are influenced by geological structures such as faults, fractures, folds, are more susceptible to landslide symptoms, especially if the direction of rock layers is in the same direction as the slope and there are active faults. Layers of rock that are interspersed between an impermeable rock and water-permeable rock create areas that have the potential as slip fields.

According to [41] landslide susceptibility is categorized into three criteria, namely very vulnerable, vulnerable, and not vulnerable. The results of spatial analysis on each parameter that causes landslides in Limau District to produce a map of landslide vulnerability areas with 2 classes of landslide susceptibility, areas non-landslide vulnerable, and areas landslide vulnerable.

Areas with a non-landslide vulnerable class are areas that generally have a low vulnerability to landslides. In Limau District, which has an area class that is not prone to landslides is $10.57 \mathrm{~km}^{2}$ or $5.05 \%$ of the total area of Limau District. Based on the table above and the Landslide Vulnerability Map in Limau District, 3 villages are non-landslide vulnerable class is Pekon Antarbrak, Pekon Ampai, and Tanjung Anom. Of the three villages, Pekon Antarbrak has the largest area for the non-landslide vulnerable class, which is $8.44 \mathrm{~km} 2$ or $4.03 \%$. Meanwhile, the small village area which is a non-landslide vulnerable class is located in the villages with an area of $0.55 \mathrm{~km} 2$ or $0.26 \%$.

Judging from the comparison of the area of the landslide vulnerable class area with the non-landslide vulnerable class area, the area that has non-landslide vulnerable class is only a small part of the total area of the Limau District. Based on the results of the study, it was found that the class that is non-landslide vulnerable class has a parameter specification of moist rainfall with a rainfall intensity of 2,000-2500 $\mathrm{mm} /$ year. The soil type parameter is dominated by latosol and alluvial soil types. Where this type of latosol and alluvial soil has a rather sensitive sensitivity and is sensitive to binding water into the soil. So that makes some of these areas less of a factor for landslides. In addition to soil type, land use in the 
area which is non-landslide vulnerable class has land use in the form of forest areas which still have a lot of vegetation in the form of large trees, so that it is very minimal when landslides occur. The slope parameter of the area with a non-landslide vulnerable class is dominated by a rather steep slope (15-25\%). Although the area has a rather steep slope and when it rains it will not affect the occurrence of landslides, judging from the abundance of vegetation in the forest, as well as the soil that is somewhat sensitive to erosion, the soil is not easy to move.

Apart from that, the land-use factor in Limau District greatly affects the occurrence of landslide vulnerability. It was found that most of the area has land use in the form of shrub vegetation and dry mixed bush farming. The use of the land is a factor that causes landslides, because the land with shrub vegetation is not able to bind soil aggregates in place, and can be a potential for landslide disasters.

In addition, the conversion of land in Limau District, which used to have many large trees, has now turned into agricultural land. Based on the results of the field survey, a lot of lands that should be used for water absorption is used as a house or agricultural land and also many hills are cleared for agricultural land without paying attention to drainage. This of course makes it homework for the Limau District government to minimize the occurrence of landslides. Although many efforts have been made to reduce landslide vulnerability. One of the efforts that can be made to reduce landslide vulnerability in landslide vulnerable class areas by the local government is to build cliffreinforcing buildings or gabions (arrangements of stones tied with wire) on road cliffs that cut slopes and setting cropping patterns in the tillage field as well as increasing soil fertility and water availability. One model of the cropping system is management that synergizes between components of trees and annuals in the same space and time.

\section{CONCLUSION}

Based on the results of the study, it can be concluded that to see the distribution of landslides that occurred in Limau District, Tanggamus Regency, it would be better to use a spatial model for each of the factors that influence it. So that the landslides that occur are divided into 2, Vulnerable and Non Vulnerable, with the largest percentage being landslide vulnerable

\section{ACKNOWLEDGMENT}

Thank you to the Institute for Research and Community Service (LP2M), University of Lampung, the Regional Government of Tanggamus Regency, and all the stakeholders involved in this research.

\section{REFERENCES}

[1] Dwikorita, K, 'Bencana Alam Gerakan Massa Tanah Di Indonesia Dan Penanggulangannya,' UGM: Yogyakarta Geologi, Yogyakarta, 2005.

[2] Sukrizal, S., Fatimah, E., \& Nizamuddin, N, 'Analysis of Landslide Hazards Area Using Geographic Information System in Gayo Lues District,' International Journal of Multicultural and Multireligious Understanding, 6(3), 193203, 2019.

[3] Hardiyatmo, H.C, 'Penanganan Tanah Longsor dan Erosi,' Gadjah Mada University Press, Yogyakarta, Hal. 308-319, 2006.

[4] Rahman, H. A, 'An Overview of Environmental Disaster in Malaysia and Prepa-redness Strategies,' Iranian Journal of Public Health, 43(Supple 3), 17-24, 2014.

[5] Bokko, J, 'Analisis Kelongsoran Jalan Poros SangallaBatualu Dengan Program Plaxis,'Journal Dynamic Saint, 4(1), 764-772, 2019.

[6] Rotaru, A., Oajdea, D., \& Răileanu, P, 'Analysis of the landslide movements. International journal of geology' 1(3), 70-79, 2007.

[7] Wahyono, S. C., Hidayat, T. A., Pariadi, P., Hapsari, P., Novianti, R. F., Dewi, R. K., \& Minarto, O, 'Aplikasi Metode Tahanan Jenis 2D untuk Mengidentifikasi Potensi Daerah Rawan Longsor di Gunung Kupang, Banjarbaru,' Jurnal Fisika Flux: Jurnal Ilmiah Fisika FMIPA Universitas Lambung Mangkurat, 8(2), 95-103, 2011.

[8] Popescu, M. E, 'Landslide causal factors and landslide remediatial options,' In 3rd International Conference on Landslides, Slope Stability and Safety of Infra-Structures (pp. 61-81). CI-Premier PTE LTD Singapore, 2002

[9] Faizana, F., Nugraha, A. L., \& Yuwono, B. D, 'Pemetaan risiko bencana tanah longsor Kota Semarang,' Jurnal Geodesi Undip, 4(1), 223-234, 2015.

[10] McColl, S. T, 'Landslide causes and triggers. In Landslide hazards, risks and disasters'(pp. 17-42), Academic Press, 2015.

[11] Mersha, T., \& Meten, M, 'GIS-based landslide susceptibility mapping and assessment using bivariate statistical methods in Simada area, northwestern Ethiopia,' Geoenvironmental Disasters, 7(1), 1-22, 2020.

[12] Voight, B., \& Elsworth, D, 'Failure of volcano slopes,' Geotechnique, 47(1), 1-31.1997.

[13] Hungr, O., Leroueil, S., \& Picarelli, L, 'The Varnes classification of landslide types, an update,' Landslides, 11(2), 167-194, 2014.

[14] Ulfa, S. Y., Pauzi, G. A., \& Warsito, W, 'Desain dan Realisasi Alat Pendeteksi Perubahan Tingkat Kemiringan Tanah sebagai Penyebab Tanah Longsor Menggunakan Sensor Potensio Linier Berbasis Mikrokontroler ATMega 8535,' Jurnal Teori dan Aplikasi Fisika, 4(1), 2016.

[15] Ciurean, R. L., Schröter, D., \& Glade, T, 'Conceptual frameworks of vulnerability assessments for natural disasters reduction,' In Approaches to disaster management-Examining the implications of hazards, emergencies and disasters. IntechOpen, 2013

[16] Rijanta, R., Hizbaron, D. R., \& Baiquni, M, 'Modal Sosial dalam Manajemen Bencana,' UGM PRESS. Yogyakarta, 2018

[17] Lihawa, F. 'Kajian bidang longsoran di DAS Alo dengan metode geolistrik,' In Seminar Nasional Riset Inovatif (Vol. 2), 2017.

[18] Berti, M., Bertello, L., Bernardi, A. R., \& Caputo, G, 'Back analysis of a large landslide in a flysch rock mass,' Landslides, 14(6), 2041-2058, 2017.

[19] Naryanto, H. S., Prawiradisastra, F., Kristijono, A., \& Ganesha, D, 'Penataan Kawasan Pasca Bencana Tanah 
Longsor di Puncak Pass, Kecamatan Cipanas, Kabupaten Cianjur Tanggal 28 Maret 2018,'Jurnal Pengelolaan Sumberdaya Alam dan Lingkungan (Journal of Natural Resources and Environmental Management), 9(4), 10531065, 2019.

[20] Pasektiono, W. W, 'Aplikasi Sig Untuk Identifikasi Daerah Rawan Longsor Di Kecamatan Tembalangkota Semarang' (Doctoral dissertation, Universitas Negeri Semarang) 2016.

[21] Khosiah, K., \& Ariani, A, 'Tingkat kerawanan tanah longsor di dusun Landungan desa Guntur Macan kecamatan Gunungsari kabupaten Lombok Barat,'Jurnal Ilmiah Mandala Education, 3(1), 195-200, 2017.

[22] Wainwright, J., Turnbull, L., Ibrahim, T. G, Lexartza-Artza I., Thornton, S. F., \& Brazier, R. E. 'Linking environmental regimes, space and time: Interpretations of structural and functional connectivity,' Geomorphology, 126(3-4), 387-404, 2011.

[23] Harto, M. F. D., Rachman, A., Aisyah, M., Abigail, N., \& Utama, W, 'Pemetaan Daerah Rawan Longsor Dengan Menggunakan Sistem Informasi Geografis Studi Kasus Kabupaten Bondowoso,' Jurnal Geosaintek, 3(3), 161-166, 2017.

[24] Wahyudi, I. D. B., Nugroho, H., Aribowo, Y., \& Yuwono, R. W, 'Integrasi Log Sumur dan Seismik 2D Untuk Analisis Karakteristik Reservoir dan Menghitung Potensi Hidrokarbon Pada Formasi Tualang, Lapangan "SHANDORA", Cekungan Sumatera Tengah,' Geological Engineering E-Journal,6(1), 112-127, 2014

[25] Agustin, A. D., \& Utama, W, 'Identifikasi Letak Cracks pada Bidang Longsor Menggunakan Metode Resistivitas 2D,' Jurnal Teknik ITS, 6(1), C103-C105, 2017.

[26] Aisyah, M., Utama, W., \& Lestari, W, 'Analisis Daerah Rawan Bencana Tanah Longsor Berdasarkan Zona Water Content di Olak Alen Kecamatan Selorejo, Blitar,' Jurnal Teknik ITS, 6(2), C122-C124, 2017

[27] Afriyani, I, 'Analisis Kelembagaan pada Masyarakat di Kawasan Hutan Kemasyarakatan (HKm) Kajian pada Masyarakat di Kawasan Register 28, 30, 32 Kabupaten Tanggamus,' 2014

[28] Arifin, S., Carolita, I., \& Winarso, G, 'Implementasi Penginderaan Jauh dan SIG untuk Inventarisasi Daerah Rawan Bencana Longsor (Propinsi Lampung), Jurnal Penginderaan Jauh dan Pengolahan Data Citra Digital, 3(1), 2010.

[29] Prawiradisastra, S, 'Identifikasi Daerah Rawan Bencana Tanah Longsor di Provinsi Lampung,' Jurnal Sains dan Teknologi Indonesia, 15(1), 2014.

[30] Lusy, I., Suwarni, N., Miswar, D., \& Jaya, M. T. B, 'Pemodelan Bencana Longsor Berbasis Spasial,' LaGeografia, 19(1), 16-27, 2020.

[31] Tika, Pabundu, 'Metode Penelitian Geografi' PT. Bumi Aksara, Jakarta, 2005.

[32] Siyoto, S., \& Sodik, M, Dasar metodologi penelitian. Literasi Media Publishing, 2015.

[33] Ridha, N, 'Proses Penelitian, Masalah, Variabel dan Paradigma Penelitian,' Hikmah, 14(1), 62-70, 2017.

[34] Sulistyo, B, Peranan Sistem Informasi Geografis Dalam Mitigasi Bencana Tanah Longsor. In Seminar Nasional Mitigasi Bencana Dalam Perancanaan Pengembangan Wilayah,' Fakultas Pertanian. Universitas Bengkulu, 2016.

[35] Chaeril, C., Tjoneng, A., \& Saida, S, 'Analisis Kerawanan Longsor Berbasis Spasial Di Kawasan Taman Nasional Bantimurung Bulusaraung,' Agrotek: Jurnal Ilmiah Ilmu Pertanian, 2(1), 54-68, 2018, Spasial. LaGeografia, 19(1), $16-27$.
36] Manik, T. K., Rosadi, B., Sanjaya, P., \& Pandu Pradana, O. C, 'Resiko Bencana; Kajian Kerentanan, Kapasitas Dan Pemetaan Risiko Bencana Akibat Perubahan Iklim,' Mobius, 2018

[37] Utama, L., \& Naumar, A, 'Kajian kerentanan kawasan berpotensi banjir bandang dan mitigasi bencana pada daerah aliran sungai (DAS) Batang Kuranji Kota Padang,' Rekayasa Sipil, 9(1), 21-28, 2015.

[38] Santoso, S., Rudiarto, I., \& Luqman, Y, 'Arahan Penataan Kawasan Permukiman Di Kota Palu Berdasarkan Kesesuaian Lahan Permukiman Terhadap Potensi Bencana Dan Kerentanan Sosial Ekonomi' (Doctoral dissertation, School of Postgraduate), 2019.

[39] Farizki, M., \& Anurogo, W, 'Pemetaan kualitas permukiman dengan menggunakan penginderaan jauh dan SIG di kecamatan Batam kota, Batam,' Majalah Geografi Indonesia, 31(1), 39-45, 2017.

[40] Pusat Penelitian dan Pengembangan Tanah dan Agroklimat (Puslittanak). 'Laporan Akhir Pengkajian Potensi Bencana Kekeringan, Banjir dan Longsor di Kawasan Satuan Wilayah Sungai Citarum-Ciliwung, Jawa Barat Bagian Barat Berbasis Sistem Informasi Geografi ’ Bogor, 2004.

[41] Subagio, H., Riacli, B., Survei, B. K., \& Nasional, P, 'Model Spasial Penilaian Rawan Longsor Studi Kasus di Trenggalek. Badan Koordinasi Survei dan Pemetaan Nasional Jakarta,' 2008.

[42] Nandi, A., \& Shakoor, A, 'A GIS-based landslide susceptibility evaluation using bivariate and multivariate statistical analyses,' Engineering Geology, 110(1-2), 11-20, 2010

[43] Arsyad, U., Barkey, R. A., Wahyuni, W., \& Matandung, K. K, 'Karakteristik Tanah Longsor di Daerah Aliran Sungai Tangka,' Jurnal Hutan dan Masyarakat, 203-214, 2018.

[44] García-Ruiz, J. M 'The effects of land uses on soil erosion in Spain: a review,' Catena, 81(1), 1-11, 2010.

[45] Hardianto, A., Winardi, D., Rusdiana, D. D., Putri, A. C. E., Ananda, F., Djarwoatmodjo, F. S., \& Gustav, F, 'Pemanfaatan Informasi Spasial Berbasis SIG untuk Pemetaan Tingkat Kerawanan Longsor di Kabupaten Bandung Barat, Jawa Barat,'Jurnal Geosains Dan Remote Sensing, 1(1), 23-31, 2020

[46] Malingreau, Jean Paul, 'Apropose Land Cover/ Land use Classification and its use With remote Sensing Data In Indonesia,' The Indonesian journal of Geography, No.33, Vol 7: Fakultas Geografi UGM, Yogyakarta, 1977.

[47] Hardjowigeno, S, 'Klasifikasi Tanah Pedogenesis. Akademika Pressindo,' Jakarta, 1993.

[48] Harjadi Et Al., Analisis Kerentanan Tanah Longsor Sebagai Dasar Mitigasi Di Kabupaten Banjarnegara (Vulnerability Analysis As A Basic For Landslide Mitigation In Banjarnegara Regency). Journal Of Watershed Management Research, Vol.1, No.1, 2017.

[49] Hardiyatmoko, H. C, 'Penanganan Tanah Longsor dan Erosi (Edisi 1),' Yogyakarta: Gadjah Mada University Press, 2016.

[50] Paimin, Sukresno \& Pramono, I. B, 'Teknik Mitigasi Banjir dan Tanah Longsor' Balikpapan: Tropenbos International Indonesia Programme, 2009.

[51] Sutikno, 'Karyotipe kromosom pada Allium sativum L. (bawang putih) dan Pisum sativum L. (kacang kapri)'. BioSmart 2(1): 20-27, 2000.

[52] Djamaludin, M. M., 'Analysis Stratigrafasi Sikuen Resolusi Tinggi Reservoir Rindu-1, Area 4, Lapangan Minyak Duri Cekungan Sumatra Tengah,'Program Pasca-Sarjana Geologi, Departemen Teknik Geologi, Fakultas Pasca-Sarjana, Institut Teknologi Bandung, Bandung, tidak dipublikasikan, 2003. 